\title{
Stimulation of antiviral cellular immune responses by therapeutic vaccination of HIV-1-infected patients with dendritic cells transfected with gag, tat, rev and nef mRNA
}

\author{
Ellen Van Gulck', Viggo F Van Tendeloo ${ }^{2,3^{*}}$, Erika Vlieghe ${ }^{4}$, Marc Vekemans ${ }^{4}$, Ann Van de Velde ${ }^{2,3}$, Evelien Smits ${ }^{2,3}$, \\ Sébastien Anguilie, ${ }^{2,3}$, Nathalie Cools²,3, Barbara Stein ${ }^{2,3}$, Griet Nijs ${ }^{2,3}$, Herman Goossens ${ }^{2}$, Liesbet Mertens ${ }^{4}$, \\ Winni De Haes ${ }^{1}$, Céline Merlin ${ }^{1}$, Derek Atkinson ${ }^{1}$, Johnsson Wong ${ }^{5}$, Eric Florence ${ }^{4}$, Guido Vanham ${ }^{1,6}$, \\ Zwi N Berneman ${ }^{2,3}$
}

From Frontiers of Retrovirology 2011

Amsterdam, The Netherlands. 3-5 October 2011

\section{Background}

In an attempt to raise protective antiviral immunity, dendritic cell (DC) immunotherapy was evaluated in 6 adults infected with human immunodeficiency virus (HIV)-1 and stable under antiretroviral therapy (HAART).

\section{Methods}

Autologous monocyte-derived DC electroporated with mRNA encoding Gag and TatRevNef fusion protein were injected 4 times at 4 weeks interval, while patients remained on HAART. Feasibility, safety and immunogenicity were investigated.

\section{Results}

DC vaccine preparation and administration was successful in all patients and only mild adverse events such as skin reactions were seen. DC vaccination induced immune responses that have been reported to be related to control of HIV-1 replication. There was a significant increase post-as compared to pre-DC vaccination, in magnitude - in particular to Gag - and breadth of HIV1 -specific interferon (IFN)- $\gamma$ response and T-cell proliferation. Breadth of IFN- $\gamma$ response and T-cell proliferation were correlated with both $\mathrm{CD} 4+$ and $\mathrm{CD} 8+$ polyfunctional T-cell responses. Importantly, DC vaccination induced or increased the capacity of autologous $\mathrm{CD} 8+\mathrm{T}$-cells to suppress superinfection of CD4+ Tcells with the vaccine-related IIIB virus and to a lesser extent with other HIV-1 strains. This CD8+ T-cellmediated HIV-1-inhibitory activity was correlated with increased breadth of Gag-specific IFN- $\gamma$ response, indicative of improved control of HIV replication. These features are indicative of improved virus control.

\section{Conclusion}

Therapeutic immunization of patients stable under HAART with DC electroporated with mRNA encoding HIV-1 antigens is safe and was successful in raising antiviral cellular immune responses, including effector CD8 $+\mathrm{T}$-cells with inhibitory activity towards infection of CD4+T-cells with a vaccine-homologous HIV strain.

\footnotetext{
Author details

'Department of Biomedical Sciences, Division of Microbiology, Virology Unit, Institute of Tropical Medicine, Antwerp, Belgium. ${ }^{2}$ Vaccine and Infectious Disease Institute, Faculty of Medicine, University of Antwerp, Antwerp, Belgium. ${ }^{3}$ Center for Cell Therapy and Regenerative Medicine (CCRG) and Division of Hematology, Antwerp University Hospital (UZA), Edegem, Belgium. ${ }^{4}$ Department of Clinical Sciences, Medical Service, HIV and STD Unit, Institute of Tropical Medicine, Antwerp, Belgium. ${ }^{5}$ Department of Medicine, Massachusetts General Hospital, Harvard Medical School, Boston, MA, USA. ${ }^{6}$ Faculty of Pharmaceutical, Biomedical Sciences and Veterinary
} 
Published: 3 October 2011

doi:10.1186/1742-4690-8-S2-P76

Cite this article as: Van Gulck et al:: Stimulation of antiviral cellular immune responses by therapeutic vaccination of HIV-1-infected patients with dendritic cells transfected with gag, tat, rev and nef mRNA. Retrovirology 2011 8(Suppl 2):P76.

Submit your next manuscript to BioMed Central and take full advantage of:

- Convenient online submission

- Thorough peer review

- No space constraints or color figure charges

- Immediate publication on acceptance

- Inclusion in PubMed, CAS, Scopus and Google Scholar

- Research which is freely available for redistribution

Submit your manuscript at www.biomedcentral.com/submit
() Biomed Central 